The 16th Economic International Conference

New Challenges and Opportunities for the Economy 4.0, May 7-8th, 2020, Suceava, Romania

\title{
Insurance and Social Asistance Expenditure from Local Budgets
}

\author{
Cristinel ICHIM
}

$\underline{\text { https://doi.org/10.18662/lumproc/ncoe4.0.2020/15 }}$

How to cite: Ichim, C. (2020). Insurance and Social Asistance Expenditure from Local Budgets. In C. Nastase (vol. ed.), Lumen Proceedings: Vol. 13. 16th Economic International Conference NCOE 4.02020 (pp. 158-170). Iasi, Romania: LUMEN Publishing House.

https://doi.org/10.18662/lumproc/ncoe4.0.2020/15 


\title{
Insurance and Social Asistance Expenditure from Local Budgets
}

\author{
Cristinel ICHIM ${ }^{1}$
}

\begin{abstract}
Social assistance includes social services and benefits provided with the purpose of developing individual or collective capacity for the purpose of meeting social needs, to increase quality of life and promote the principles of social cohesion and inclusion. The present paper aims to deal with a significant category of expenditure financed from local budgets, namely insurance and social assistance expenditure. The first part of the study includes a clarification of the content and role of these expenditures in the work of local public authorities. Research continues with quantitative analysis of the insurance and social assistance expenditure in local budgets on the basis of existing data in the Statistical Yearbook of Romania and highlights the place it takes in this category of spending in local budgets as well as their evolution in recent years The results of the research show that the evolution and structure of insurance and social assistance financed from local budgets is determined by action of variables which differ from one territorial administrative unit to another: number and social structure of the population, specific legislation on social assistance, social services and benefits provided, etc.
\end{abstract}

Keywords: local budget; expenses ; insurance and social assistance; social services and benefits ; disability.

1 Ph.D. Lecturer on "Ştefan cel Mare" University of Suceava, Romania,
cristinel.ichim@,usm.ro 


\section{Introduction}

Local public expenditures can be defined as being the amounts approved and made from the components of the general consolidated budgets of the territorial administrative units within the limits and according to the destinations established by the respective budgets, in compliance with the legal provisions. Thus as I shown in a different context „unlike state budget expenditures, local budget expenditures reflect the financial efforts made by local public administration bodies to cover the social, cultural, economic, public development services and other requirements of the inhabitants of the administrative-territorial units within the jurisdiction of local public authorities" [2].

Due to the importance for the general evolution of the local communities, respectively through the shares they occupy in the local budgets, the public expenditures for insurance and social assistance financed from these budgets stand out. Some authors [1] appreciate that this category of expenses "concretizes the intervention of public authorities to influence social life, by supporting individuals who are part of certain social categories." From the own budgets of the territorial administrative units are financed the expenses regarding the social assistance in case of diseases and disability, social assistance for family and children, aid for housing, nurseries, prevention of social exclusion through social aid and social aid canteens. Expenditure on social assistance and protection from local budgets is largely mandatory in the sense that it is set by central authorities and financed by transfers from the state budget.

\section{Aims of the research}

The rational and efficient use of local public funds requires a detailed analysis of public expenditure in local budgets in order to set priorities in the allocation of financial resources and measures to improve their management. Insurance and social asistance have an important role in local public expenditure as it covers social services and social benefits provided to develop individual or collective capacities for social needs, to increase quality of life and promote the principles of social cohesion and inclusion.

The aim of this work is to deepen this category of expenditure financed from local budgets by identifying the economic content and analyzing in quantitative terms their evolution in local budgets in the period 2009-2018. Our scientific approach will highlight the role and structure of public spending on social assistance and insurance in local budgets. 


\section{Research Methods}

This article combines elements of basic research with those of applied research. Thus, in the structure of fundamental research, we have dealt with the conceptual framework of social insurance and social asisstance expenditure financed from local budgets, the forms of coverage of this expenditure, the way in which social services are provided, and the provision of social benefits to beneficiaries.

Among the research methods specific to the fundamental research that we used in this work we recall: recording, classifying, measuring and comparing all the characteristics/quantitative data. In the structure of applied research, the method used is the quantitative analysis of the budgetary indicator "expenditure on insurance and social assistance", Based on the data available in the Romanian Statistical Yearbook 2010-2019 [7] to highlight the place and role that this category of expenditure in local budgets occupies in the expenditure of Romanian local budgets and to formulate some assessments on the rational and efficient use of funds public.

\section{Financing social assistance from local budgets}

Social assistance includes social services and social benefits provided in order to develop individual or collective capacities to ensure social needs, improving the quality of life and the ensuring cohesion and social inclusion. Social services and social benefits are provided according to the situation of the person or family, in accordance with the legislation in force.

Social services represent the complex set of measures and actions taken to respond to the social needs of individuals, families, groups or communities, in order to prevent and overcome situations of difficulty, vulnerability or dependence. Social services can be organized in various forms, established by the nomenclature of social services, in the form of primary services and specialized services.

The provision of social services is organized in a decentralized system, at the level of local communities, in order to respond as adequately as possible to the identified social needs, the typology of potential beneficiaries and the particular conditions in which they are.

Social benefits represent financial transfers and include: family allowances, social benefits, allowances and facilities. Family allowances are granted to families with children and mainly concern the birth, education and children maintenance.

Social benefits are benefits provided in cash and in kind to persons or families in difficulty and whose income is insufficient to cover the 
minimum living needs assessed by social survey, as well as by other specific instruments.

The way of financing the social assistance is established by the special laws that regulate the granting of social benefits and the provision of social services.

From the county budgets, the local budgets of the sectors of Bucharest and from the budget of Bucharest are allocated funds for financing social services organized at the county level, sectors of Bucharest and Bucharest and for financing social benefits established by decisions of county councils, General Council of the Municipality of Bucharest, of the local councils of the sectors of the municipality of Bucharest, of the municipalities, of the cities and of the communes or by special laws, as the case may be.

From the county budgets it is possible to ensure the financing in partnership of the social services developed at the level of municipalities, cities and communes. The local budgets of municipalities, cities and communes ensure the financing of social services provided by local councils, alone or in partnership (forms of association of civil society and social assistance and facilities provided locally).

Local councils at all levels of local public administration have the obligation to provide in their own budgets, separately, the necessary funds for social services social benefits, established by special laws and decisions of local councils.

To finance social services are also used amounts from own income, donations, sponsorships or other contributions from individuals and legal entities, from the country and abroad, as well as from other sources, in compliance with the relevant legislation. Depending on the income, the beneficiaries contribute to the financing of social services.

The legislation stipulates that "at the annual substantiation of the amounts necessary to ensure the payment of social assistance benefits, the following elements are taken into account: a) the number of beneficiaries registered in the previous year; b) estimating the number of beneficiaries for the budget year according to the economic, demographic and social evolutions, as well as to the registered macroeconomic indicators; c) the nominal amount or, as the case may be, the average amount of the social assistance benefit. The budgetary substantiation and the social assistance benefits to be granted, approved in accordance with the law, shall be taken into account" [6]. 


\section{Expenditure from local budgets for social assistance provided to the elderly}

The elderly person is the person who has reached the legal retirement age. Elderly people receiving social assistance are also entitled to other forms of social protection. Social assistance for the elderly is provided through social services and benefits.

These rights benefit the elderly person who has no family or is not dependent on one or more persons obliged to do so, according to the legal provisions in force; the elderly person does not have home and the possibility to ensure his living conditions based on his own resources; does not make his own income or it is not enough to provide the necessary care; he cannot manage on his own and needs specialized care or can't provide for him medical needs and social needs due to illness or physical or mental condition.

Community services for the elderly are carried out with their consent and include temporary or permanent care at home or in a home for the elderly, as well as care in day centers, clubs for the elderly, temporary care homes, apartments and social housing, and the like. Community services provided to the elderly in homes are social services, socio-medical services and medical services. The financing of these services is ensured on the principle of division of responsibility between the central and the local public administration [3].

Social assistance for the elderly is provided with support from the state budget, for: financing the social assistance activities carried out by Romanian associations and foundations with legal personality, as well as by the cult units recognized in Romania; to provide investment and capital repairs for social assistance units in disadvantaged areas, to supplement the own revenues of households, when local budget resources become insufficient and for other expenditures established by annual budget laws.

From the local budget, are financed the subsidies granted in addition to the own incomes of the retirement homes, the social assistance activities of some Romanian associations and foundations with legal personality, as well as of the cult units recognized in Romania, the expenses for the organization and functioning of the community social assistance services as well as for home care and funeral expenses. Social assistance for the elderly can be financed by Romanian and foreign individuals and legal entities through sponsorships and donations in cash or gifts in kind, made directly to homes for the elderly or to institutions specializing in social services.

The investments for the construction, endowment, maintenance, modernization, as well as the expenses for the operation of the retirement 
homes that serve several administrative-territorial units are financed according to the agreements concluded between the financier and the interested local councils.

Expenditures for medical services, sanitary materials, medical devices and medicines are made from the funds and under the conditions provided by the regulations on social health insurance. The expenses that are not supported from the social health insurance funds are insured by the retirement home, through which the assistance of the person in question is provided.

\section{Expenditure from local budgets for social assistance in case of disability [5]}

The social assistance institutions for the disabled are structures without legal personality subordinated to the county councils, respectively to the local councils of the sectors of the Bucharest municipality. The financing of social assistance institutions for people with disabilities is ensured from amounts allocated from the budgets of local public administration authorities, amounts deducted from some revenues of the state budget, amounts allocated from the state budget, own contributions of beneficiaries or their maintainers, which with the law will be paid into the account of the centers, and other incomes earned under the law.

The financing of the social assistance institutions for the disabled persons is done directly by the county councils, respectively by the local councils of the sectors of the Bucharest municipality. In order to ensure equal opportunities in social life, children with severe disabilities benefit from rights financed from local budgets for personal assistant, employed by local public authorities, based on the recommendations of the social survey conducted by a commission within the specialized department of the mayor's office in whose territorial area the child resides.

The parents or legal representatives of the child with a severe disability may choose to receive an allowance equivalent to the net salary of the novice social worker from the budget units or for a personal assistant. For children with severe and severe disabilities and for their personal assistants, free of charge is granted for urban transport by public surface transport or by subway, based on a social survey carried out by the social worker within the specialized department of the mayor's office where the disabled child has a domicile or residence.

The parents or legal representatives of the child with a severe disability may choose to receive an allowance equivalent to the net salary of the novice social worker from the budget units or for a personal assistant. 
For children with accentuated and severe disabilities and for their personal assistants, free of charge is granted for urban transport by public surface transport or by subway, based on a social survey carried out by the social worker within the specialized department of the mayor's office where the disabled child has a domicile or residence.

On the other hand, in order to ensure the right to social security, as well as the right to health care and training, adults with severe disabilities benefit from rights financed from local budgets for personal assistant, employed by the local public administration authority, based on recommendations the social investigation carried out by a commission within the specialized department of the mayor's office in whose territorial area the respective person has his domicile or residence. The severely disabled person or his legal representatives, except for the blind, may opt for an allowance equivalent to the net salary of the novice social worker in the budget units or for the personal assistant.

The personal assistant carries out his activity on the basis of the individual employment contract, concluded with the local public administration authorities in whose territorial area the person with a severe disability has his domicile or residence. The personal assistant of the disabled person is paid in relation to the legal provisions regarding the salary of the debutant social worker, with secondary education, from the budgetary units.

\section{Expenditure from local budgets for social assistance for family and children}

At the county level, the General Directorate of Social Assistance and Child Protection operates and the financing of the General Directorate is ensured from the local budgets of the counties, respectively from the local budgets of the sectors of Bucharest. Also, under the subordination of the county council, respectively of the local council of Bucharest, operates the Commission for child protection, as a specialized body, without legal personality, of the county council, respectively of the local council of the sector of Bucharest, with decisional activity in protection and the promotion of children's rights.

At the level of communes, cities and municipalities, public social assistance services operate. The legislation in the domain [4] stipulates ,the public social assistance services organized at the level of municipalities and cities, as well as the persons with social assistance attributions from the own apparatus of the local councils monitor and analyze the situation of the children from the administrative-territorial unit, as well as the observance of the children's rights, providing the centralization and collation 
of relevant data and information, and performs the activity of preventing the separation of the child from his family".

In order to prevent the separation of the child from his parents, as well as to achieve the special protection of the child separated, temporarily or permanently from his parents, day services in the form of day centers are provided, also counseling and support centers for parents, assistance and support centers for the rehabilitation of the child with psychosocial problems; monitoring, assistance and support services for pregnant women prone to childbirth.In addition to day services, family and residential services such as placement centers, emergency reception centers and maternal centers may operate. The day services established by the county council or by the local councils of the sectors of Bucharest operate as units without legal personality in the structure of the General Directorate of Social Assistance and Child Protection and are addressed only to children who benefit from a special protection measure.

In order to avoid separation of the children from his parents, local authorities must organise daycare services. If the local council identifies financial funds and human resources sufficient to organise daycare services, at its request, county council will alocate financial resources to organise this type of services. The prevention of separation of the child from his family as well as the special protection of the child temporarily or permanently deprived of the protection of his parents are financed from the local budget of territorial administrative units, local budgets of counties and sectors of Bucharest, state budget and donations, sponsorships and other private and lawful forms of monetary contributions.

Expenditures for the payment of salaries or allowances for foster carers are borne by the county budget, respectively from the budget of the Bucharest municipality sector, and are managed by the General Directorate of Social Assistance and Child Protection.

Mayors provide exceptional financial benefits, in the event that the family caring for the child temporarily has financial problems caused by unhelpful surroundings, and which endangers the normal development of the child. Exceptional benefits are given as a priority to children whose families do not have the possibility or ability to provide the child with appropriate care due to the need to bear particular expenses intended to maintain the child's connection with his family.

The maximum amount and the conditions for granting exceptional financial benefits are established by decision of the local authorities [4]. 


\section{Analysis of the dynamics of expenditure for insurance and social assistance financed from local budgets in Romania}

In order to highlight the role and place of insurance and social assistance expenditures in local budgets, we will perform an analysis of their evolution as well as the shares of this category of expenditures in the centralized budget of territorial administrative units in Romania in the period 2009-2018. We will do this scientific approach based on the data available for this purpose in the Statistical Yearbook of Romania processed and centralised in the table beneath.

Table no. 1 Dynamics of expenditures for insurance and social assistance and of the total expenditures of local budgets in the period 2009-2018

milion lei

\begin{tabular}{|c|c|c|c|c|c|c|c|c|c|c|}
\hline $\begin{array}{c}\text { Total } \\
\text { expenditure } \\
\text { s }\end{array}$ & 2009 & $\mathbf{2 0 1 0}$ & $\mathbf{2 0 1 1}$ & $\mathbf{2 0 1 2}$ & $\mathbf{2 0 1 3}$ & $\mathbf{2 0 1 4}$ & $\mathbf{2 0 1 5}$ & $\mathbf{2 0 1 6}$ & $\mathbf{2 0 1 7}$ & $\mathbf{2 0 1 8}$ \\
\hline $\begin{array}{c}\text { Insurance } \\
\text { and social } \\
\text { assistance } \\
\text { expenditure } \\
\text { s }\end{array}$ & 6368,4 & 6743,4 & 5769,7 & 5891,3 & 6316,4 & 6527,5 & 7530,5 & 8901,1 \\
4 & 433, & $\begin{array}{l}47380, \\
4\end{array}$ & $\begin{array}{l}52101, \\
1\end{array}$ & $\begin{array}{l}59048, \\
5\end{array}$ & $\begin{array}{l}56284, \\
7\end{array}$ & 1134, & $\begin{array}{l}57275, \\
4\end{array}$ \\
\hline $\begin{array}{c}\text { Share of } \\
\text { insurance } \\
\text { and social } \\
\text { assistance } \\
\text { in total } \\
\text { expenditure } \\
\text { s (\%) }\end{array}$ & 15,13 & 16,36 & 13,11 & 12,71 & 13,33 & 12,52 & 12,75 & 15,81 & 17,13 & 22,77 \\
\hline
\end{tabular}

Source: Processing according to the Statistical Yearbook of Romania 2010-2019

We remark a sinusoidal evolution of the expenditures for insurance and social assistance from the local budgets. Thus, after an increase to the value of 6743.4 million lei in 2010, there is a decrease in 2011 to the amount of 5769.7 million lei. We note that in the next analysis period there is a significant increase in nominal size of this category of expenditures from local budgets from 5891.3 million lei in 2012 to 13042.8 million lei in 2018 . This dynamic is due to legislative changes in the field and significant increases in the amounts of social benefits granted to people / families in difficulty and financial support for people with disabilities. In this sense, we identify the year 2018 when the expenses for insurance and social assistance from the local budgets increased to the value of 13042.8 million lei in the conditions in which the total expenses from the local budgets decreased 
significantly compared to the previous year. We must mention that this year came into force some legal provisions that consistently increased the salary rights of personal assistants of people with disabilities but also the amounts of social benefits granted to people with disabilities.

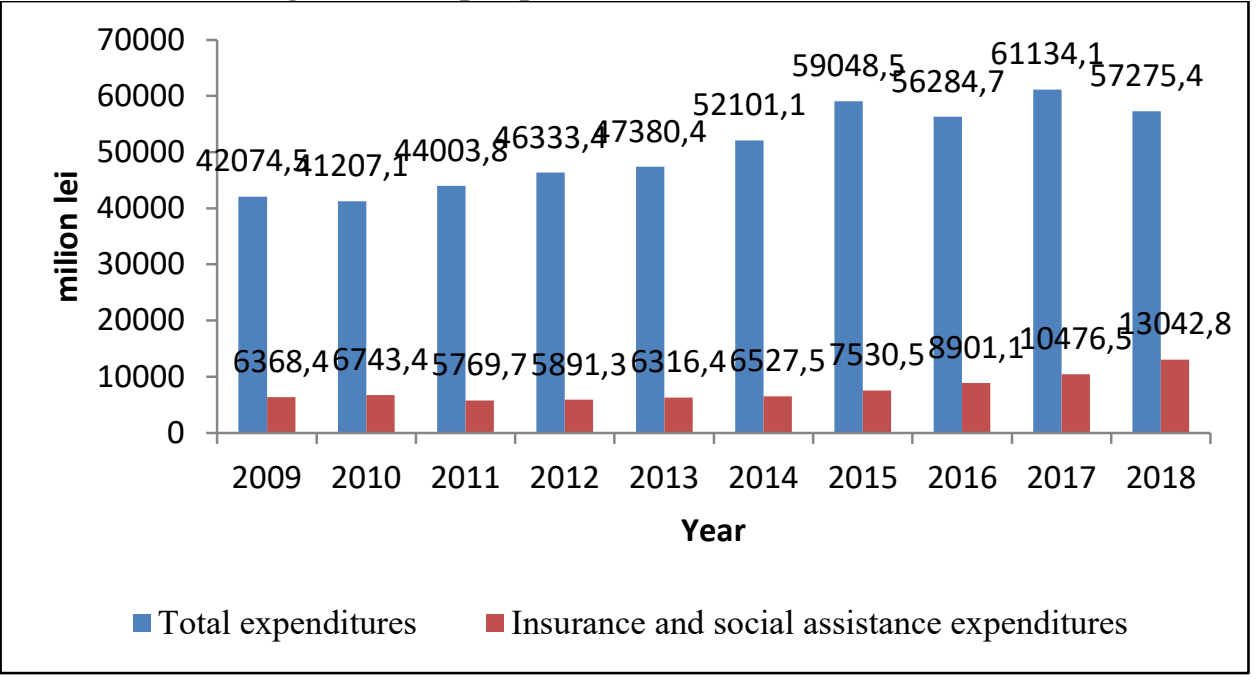

Figure no. 1 Evolution of total expenditures and expenditures for insurance and social assistance from local budgets in the period 2009-2018

The above graphic representation highlights the dynamics of total expenditures compared to the dynamics of expenditures for insurance and social assistance in local budgets. It is observed that the two variables follow the same trend of increase or decrease except for the years 2010 and 2018. This fact is explained by the fact that in 2010 the effects of the economic crisis were manifested which determined a decrease of total expenditures from local budgets and a increase in spending on insurance and social assistance from local budgets. The decrease of the total expenditures from the local budgets from 2018 was the consequence of the modification of the philosophy of financing the personnel expenditures from the state preuniversity education by giving up their payment through the local budgets.

From the perspective of the share of expenditures for insurance and social assistance from local budgets in the total expenditures from local budgets in Romania in the analyzed period we can say that the situation is similar to the one shown below (fig. No.2). 
Cristinel ICHIM | Lumen Proceedings 13 | NCOE4.0 2020

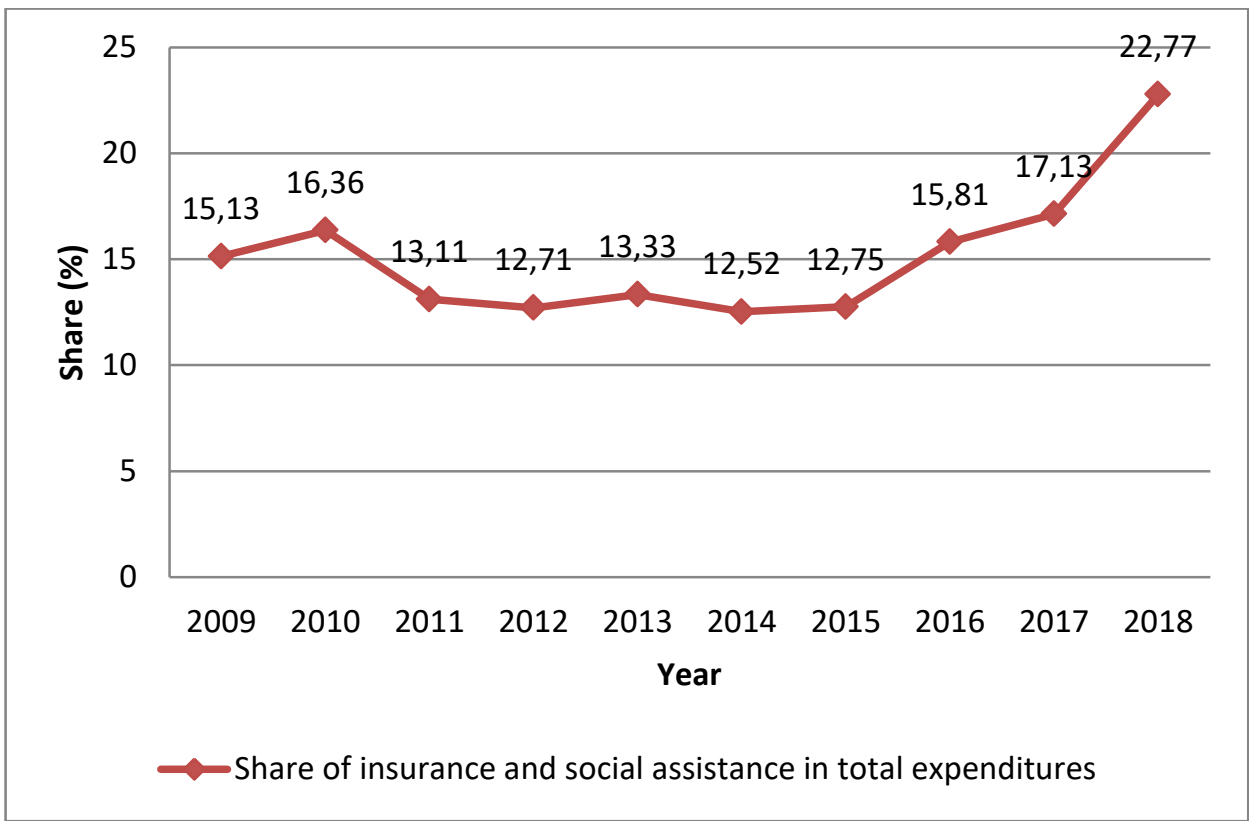

Figure no. 2 Evolution of the share of expenditures for insurance and social assistance in the total expenditures of local budgets in the period 2009-2018

Thus, after 2010, when we register a share of $16.36 \%$, there are five years in which we register shares around $13 \%$ so that at the end of the period the share of expenditures for insurance and social assistance from local budgets in total expenditures from local budgets to reach the value of $22.73 \%$. We consider that the share of expenditures for insurance and social assistance from the local budgets in the total expenditures from the local budgets is very high, being necessary the urgent intervention of the authorities in legislative plan in order to diminish it.

\section{Conclusions}

The current research gives us the posibility to detach some significant aspects with the role of conclusions regarding the public expenditures for insurance and social assistance done from the budgets of local communities.

The importance of this category of expenditure is highlighted because it covers social services and social benefits provided in order to develop individual or collective capacities to ensure social needs, increase the quality of life and promote the principles of cohesion and social inclusion. Social services and social benefits are provided according to the situation of 
the person or family, in accordance with legal provisions. From the local budgets are financed the expenses regarding the social assistance in case of diseases and disability, social assistance for family and children, aid for housing, nurseries, prevention of social exclusion through social aid and social aid canteens.

Due to their character, for the financing of public expenditures for insurance and social assistance from local budgets "caution is required in establishing the eligibility of beneficiaries, especially in the context in which it is decided at local level and the financial resources to be allocated are transferred from the central budget" [1]. These circumstances determine favorable premises to unburden local public authorities that do not mobilize their own financial resources and are not directly interested in the rationalization of final financial consumption. On the other hand, in order to determine the level and criteria of eligibility for the granting of insurance and social assistance rights, it must be taken into account that they become mechanisms to encourage beneficiaries to be interested in obtaining the income necessary for normal living.

The analysis of the dynamics of expenditures for insurance and social assistance financed from local budgets highlights the fact that this category of expenditures accounts for almost a quarter of the total expenditures of local budgets in Romania. We believe that central and local authorities must take measures to reduce spending on insurance and social assistance, in order to make possible the increase of other categories of spending supported by local budgets that have a positive influence on the socio-economic development of territorial administrative units.

\section{References}

[1] Oprea F, Cigu E. Local public finances. Bucharest: C. H. Beck Publishing House; 2013.

[2] Ichim C. Public expenditure on health in local budgets, The USV Annals of Economics and Public Administration (ISSN 2285 - 3332, ISSN-L 2285 - 3332, On-line ISSN 2344-3847), 2017; Vol. 17, Issue 1(25): 129135;

[3] Romanian Parliament. Law no. 17/2000 on social assistance for the elderly republished in the Official Monitor of Romania, Part I no. 157 of March 6, 2007 with subsequent amendments and completions, art. 20-23; 2000. 
[4] Romanian Parliament. Law 272/2004 on the protection and promotion of children's rights, republished in the Official Monitor of Romania, Part I, no. 159 of March 5, 2014, art. 118; 2004.

[5] Romanian Parliament. Law no. 448/2006 on the protection and promotion of the rights of persons with disabilities, republished in the Official Monitor of Romania, Part I, no. 1 of January 3, 2008, with subsequent amendments and completions; 2006.

[6] Romanian Parliament. Law no. 292/2011 on social assistance, published in the Official Monitor of Romania, Part I, no. 905 of 20.12.2011 with subsequent amendments and completions, art. 129 paragraph 2 and 3; 2011.

[7] Romanian Statistical Yearbook 2010-2019 